\title{
Oviposition behavior and performance aspects of Ascia monuste (Godart, 1919) (Lepidoptera, Pieridae) on kale (Brassica oleracea var. acephala)
}

Patrícia Diniz Catta-Preta ${ }^{1}$ Fernando Sérgio Zucoloto ${ }^{1}$

\begin{abstract}
Host part selection by ovipositing females of Ascia monuste (Godart, 1919) (Lepidoptera, Pieridae) on kale (Brassica oleracea var. acephala) was determined in greenhouse and field. Performance of offspring (larval period, efficiency of food utilization, number of eggs/female and others) was investigated under laboratory conditions. In the field, the number of $A$. monuste egg clutches on the apical and medium parts of kale leaves was greater than on the basal part. In greenhouse, A. monuste exhibited a strong preference for the apical part of kale leaves for ovipositing. The best results on food utilization indices, pupal mass and female wing size were obtained with the leaf apical part. This part of kale leaves exhibited the highest nitrogen and protein concentration and the smallest water content, when compared to the other leaf parts. However, the apical part of the leaves seems not to provide ovipositing females with enough protection against birds, making them easy preys in the field. We suggest that good relationship between oviposition preference and performance of offspring was hindered by predation in field conditions.
\end{abstract}

KEYwORDs. Brassicaceae; host parts selection; offspring performance; Pieridae; predation.

\section{INTRODUCTION}

Most hypotheses on the evolution of oviposition behavior agree that females choose plant species, individual plant or plant parts that maximize larval survival and growth. However, allelochemicals, nutritional chemistry, plant morphology, natural enemies and feeding modes (parasitism vs. grazing) have been pointed out as major determinants of host preference and specificity (Thompson \& Pellmyr 1991).

Ehrlich \& Murphy (1988), Quiring (1992) and Kause et al. (1999) discussed about the role of plant chemistry in plantherbivore coevolution. However, PRICE et al. (1980) and BERNAYS \& Graham (1988) believe that natural enemies of herbivore insects provide a major selection pressure for a restricted range of host plants.

Many authors found good relationship between oviposition preference and performance of offspring (RAUSHER 1982; CRAIG et al. 1989; Haussmamn \& Miller 1989; Kouki 1993). YamaGa \& Ohgushi (1999) found the same results, but the natural enemies had a high importance in the larval survival rates. On the other hand, other authors did not find any relationship
(COURTNeY 1981, 1982; RAusher 1983; DAMmAn 1987; RoInINEN \& TahVANainen 1989; Valladares \& Lawton 1991; FernandesDa-Silva \& Zucoloto 1993; OhSAKI \& Sato 1994, 1999; Berdegú́ et al. 1998).

Barros \& ZuColoto (1999) demonstrated that $A$. monuste (Godart, 1919) butterflies preferred ovipositing in brassica species that presented a good performance of offspring and higher nitrogen and protein concentration, suggesting a different oviposition strategy of monophagous species. In previous studies, Fernandes-DA-Silva \& Zucoloto (1993) showed that nutritional differences (carbohydrate concentration) might exist among different parts of the same host, but it was not clear if Ceratitis capitata (Wiedmann, 1924) (Diptera) females prefer to oviposit in the part of the fruit which is more adequate for the larvae.

Field observations showed that there are three main oviposition sites of $A$. monuste on the kale leaves (B. oleracea): apical, medium and basal parts of the leaf (Figs. 1a, 1b, 1c, respectively).

The purpose of this study was (1) to determine the oviposition behavior pattern in the absence of their predators

\footnotetext{
1. Departamento de Biologia, Faculdade de Filosofia, Ciências e Letras da Universidade de São Paulo. Av. Bandeirantes 3900, 14049-901 Ribeirão Preto-SP, Brazil. E-mail: zucoloto@ffclrp.usp.br
} 
(in most cases, birds), and (2) to assess the nutritive value of these different parts of the same kale leaf for $A$. monuste.

The white butterflies (A. monuste) used in this experiment are common in the study area (São Paulo State, Brazil) and their eggs are only found on Brassicaceae family (group assembled by the presence of glucosinolates like sinigrin). The eggs are laid in clutches mainly on the leaf surfaces and normally hatch in five days. Caterpillars usually feed at initial instars on the part of the leaf where the eggs were laid (DINIZ 1998). The mean larval period is ten days. The pupal phase takes place either on the soil or plants. The adults emerge in five days on average, and present mean life duration of five days (Shima \& GobBI 1981). In this work, the most important natural enemies of $A$. monuste butterflies and caterpillars were birds.

\section{MATERIALAND METHODS}

\section{Oviposition behavior}

The eggs were collected from an 86-plant vegetable garden kept at $90 \mathrm{~m}^{2}$ of the Departamento de Biologia, Faculdade de Filosofia, Ciências e Letras-USP experimental garden, at the outskirts of the laboratory. The kale (B. oleracea) leaves were obtained from an organically grown farm (Chácara Boa Esperança, Ribeirão Preto-SP, Brazil) nearby the university.

The couples of butterflies obtained from eggs at the vegetable garden and reared in the laboratory were placed in iron-made cages covered with tulle $(1.0 \times 1.5 \times 0.5 \mathrm{~m})$. Each cage was placed over two kale plants at the greenhouse, at $28 \pm 5{ }^{\circ} \mathrm{C}$ and about $75 \%$ relative air humidity. The photoperiod was approximately $12 \mathrm{~h} /$ day in the summer. Cages also were used for excluding birds (SIPURA 1999).

A sucrose solution was prepared by dissolving $20 \mathrm{gr}$ of reagent-grade sucrose (Merck, Darmstadt, Germany) in $200 \mathrm{ml}$ of drinking water and $2 \mathrm{gr}$ of food-grade yellow or blue dye, and offered daily on a Petri dish $(50 \times 16 \mathrm{~mm})$ to the butterflies (BArros \& Zucoloto 1999). After five days, the leaves were removed and the egg clutches counted. The number of egg clutches in each part of the leaf (basal, medium and apical increasing distance to the peduncle), characteristics of the kale leaf and of the egg clutch were noted.

\section{Performance of offspring}

The following parameters were employed to assess the nutritional value of different parts of the host chosen by $A$. monuste: larval period (days), indices of food consumption and utilization (AD, ECI and ECD), pupal mass (mg), percentage of adult emergence, wing size (mm) and number of eggs/female.

Fresh parts of the leaf to be tested (apical, medium or basal) were placed on slightly moistened filter paper in acrylic boxes $(11 \times 11 \times 3 \mathrm{~cm})$ with $1 / 3$ of the newly hatched caterpillars from one single clutch. One single source of food was supplied to each set of test caterpillars until they reached the target growth stage.

In the fifth instar, each caterpillar was transferred to a cylindrical glass vial $(10 \mathrm{~cm}$ high $\times 3 \mathrm{~cm}$ diameter) covered with gauze, where each was allowed to feed from the same food source during $24 \mathrm{~h}$ (Felipe \& Zucoloto 1993). The boxes and the vials were placed in incubators at $29 \pm 1^{\circ} \mathrm{C}$, about $75 \%$ relative air humidity, and illuminated for $10 \mathrm{~h} /$ day from a $400 \mathrm{~lx}$ fluorescent light bulb. The fifth instar is representative of the immature phase (Felipe \& ZuCOLOTO 1993).

The amount of food consumed, fecal matter produced and weight gained by individual fifth-instar caterpillars were determined on a dry weight basis using methods described by Slansky \& Scriber (1985) and Felipe \& Zucoloto (1993). The dry weight of ingested food was calculated as the difference between the dry weights of leaves left over by the caterpillar and those of the initial food. The weight gained by the insect was calculated as the difference between the dry weights of caterpillars $(\mathrm{n}=10)$ before and after feeding for $24 \mathrm{~h}$ (CORBITT et al. 1996). The samples were dried in oven at $80^{\circ} \mathrm{C}$ for $24 \mathrm{~h}$. Indices of consumption, digestion and utilization of food were described by SLANSKY \& SCRIBER (1985) and CORBITT et al. (1996).

The amount of ingested food that is digested (AD) was calculated as:

$$
\mathrm{AD}=\frac{\text { Dry weight } \text { of food ingested }(\mathrm{g})-\text { Dry weight of feces }(\mathrm{g})}{\text { Dry weight of food ingested }(\mathrm{g})} \times 100
$$

The efficiency of conversion of ingested food to body matter (ECI) which is a measure of the overall efficiency of an insect to grow on a given food, was calculated as:

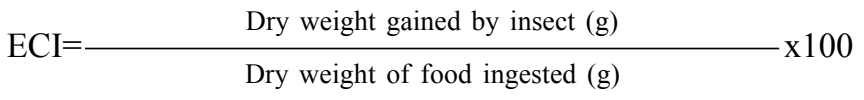

The efficiency with which digested food is converted to body matter $(\mathrm{ECD})$ was calculated as:

$\mathrm{ECD}=\frac{\text { Dry weight gained by insect }(\mathrm{g})}{\text { Dry weight of food ingested }(\mathrm{g})-\text { Dry weight of feces }(\mathrm{g})} \times 100$

For other parameters that require living insects, the caterpillars were kept in the boxes $(n=15)$ until the target-stage. After adult's emergence, couples of butterflies were placed in cages and each cage was placed over two kale plants at the greenhouse. The wing size was estimated by measuring the right wing $\mathrm{M}$-Cubital nervure $\left(\mathrm{M}_{3}\right.$ to $\left.\mathrm{Cu}_{1 \mathrm{a}}\right)$ in 10 frozen females (ZuColoto 1991).

\section{Chemical composition of the kale leaves}

Twenty fresh kale (B. oleracea var. acephala) leaves were split into the three studied parts and weighed immediately after sampling. The samples were dried in oven at $100^{\circ} \mathrm{C}$ for $72 \mathrm{~h}$. Percent water content was calculated as

$$
\left(1-\frac{\text { Dry weight }}{\text { fresh weight }}\right) \times 100
$$

(QUIRING 1992). The leaves, dried as previously described, were 

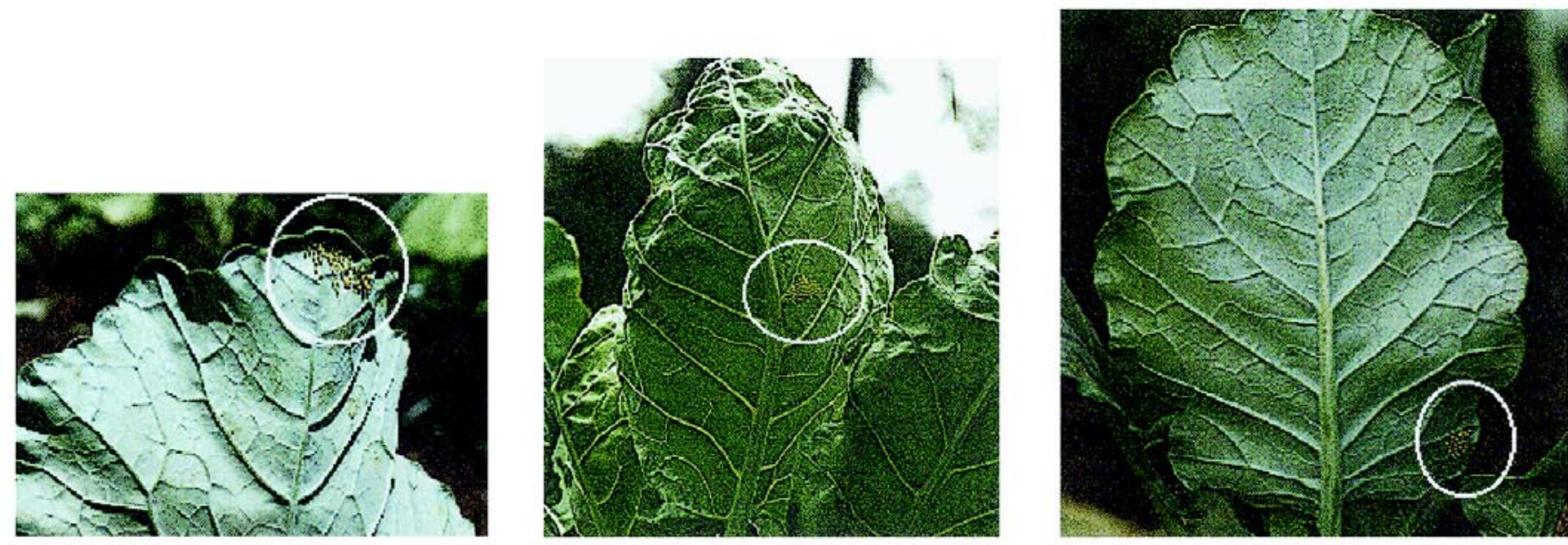

Fig. 1. Ascia monuste (Godart, 1919), egg clutches on apical, medium and basal parts, respectivaly, of the kale leaf (Brassica oleracea var. acephala).

ground and the total organic nitrogen content was determined by the Kjeldhal method (Fleck \& Munro 1965; Bremner \& MulVANEY 1982 apud QUIRING 1992).

\section{Data analysis}

Data were tested using Kolmogorov-Smirnov test to verify normality. One-way Analysis of Variance (ANOVA) and StudentNewman-Keuls test were used for Matched Data with Gaussian distribution of means. Friedman Repeated Measures ANOVA on Ranks and Student-Newman-Keuls test were used for Matched Data with not Gaussian distribution of means. Both were used with the level of significance set at a $=5 \%$ (SigmaStat for Windows, 1994- Jandel Corporation; Manugistics Inc, 1993).

\section{RESULTS}

\section{Oviposition behavior}

In the field, the mean values of number of egg clutches on the apical part of the leaf $(1.60 \pm 0.84)($ mean \pm SD) was not statistically different from the medium part $(2.90 \pm 0.99)$ and higher than on the basal part $(0.50 \pm 0.71)(\mathrm{P}=0.0024)$. However, in greenhouse the number of egg clutches (Fig. 1) on the apical part of the leaf $(3.10 \pm 1.29)$ was statistically different from the medium $(1.30 \pm 1.34)$ and the basal part $(0.60 \pm 0.70)(\mathrm{P}=0.0029)$ (Fig. 2).

\section{Performance of offspring}

Some parameters demonstrate that the apical part of the leaf is a better food source than the medium and basal parts. Caterpillars reared on the apical part had a shorter larval period, lower values of $\mathrm{AD}$ and higher values of ECD. Caterpillars reared on the medium part had a short larval period, but high values of $\mathrm{AD}$ for low values of ECD. The basal part provided a longer larval period, lower values of $\mathrm{AD}$ and lower values of ECD (Table I). Pupae and adults of A. monuste whose caterpillars were reared on the apical and medium parts grew well, but pupae and adults from the apical part were bigger than from medium part.
The basal part was a poor food source, promoting lower values of pupal mass and of percentage of emergence (Table II).

\section{Chemical composition of kale leaves}

Total protein and nitrogen are statistically more concentrated in the older part of the leaf (apical) than in the younger ones (medium and basal) (Student-Newman-Keuls method with $\mathrm{P}=0.01$ in both cases). The total protein contents were $28.5 \pm$ $1.90 \%, 26.1 \pm 0.56 \%$ and $24.3 \pm 0.41 \%$ (mean \pm SD) for apical, medium and basal parts of the leaf, respectively. Similarly, nitrogen contents were $4.56 \pm 0.31 \%, 4.18 \pm 0.08 \%$ and $3.89 \pm$ $0.06 \%$ for apical, medium and basal parts of the leaf, respectively. The opposite happens with water content. The basal part has statistically more water than medium and than apical parts, i.e., $90.4 \pm 0.35 \%$ (mean $\pm \mathrm{SD}$ ) on basal part versus $88.3 \pm 3.40 \%$ on medium part versus $86.9 \pm 1.99 \%$ on apical part of the kale leaf (Student-Newman-Keuls method with $\mathrm{P}<0.001$ ).

\section{DISCUSSION}

In a previous study, $A$. monuste butterfly chose to oviposit their eggs on adult leaves (with the greatest development and size), on the dorsal face of the leaf (where there is no direct sunlight incidence) and on the limb region (few or no clutches on the central nervures) (as also founded by BASTOS et al. 1997). The symmetry of the egg clutches was partially kept (the distance between eggs and its distribution was not the same for all eggs), even though the number of asymmetrical clutches was small (Diniz 1998). This suggests that the greenhouse conditions used in this study were adequate to mimic the natural environment.

Most parameters measured in the greenhouse experiments were comparable to the ones measured in the field, except the distance of the egg clutches to the leaf peduncle. In the field, the number of egg clutches on the apical part of the leaf was not statistically different from the medium part, but was bigger 

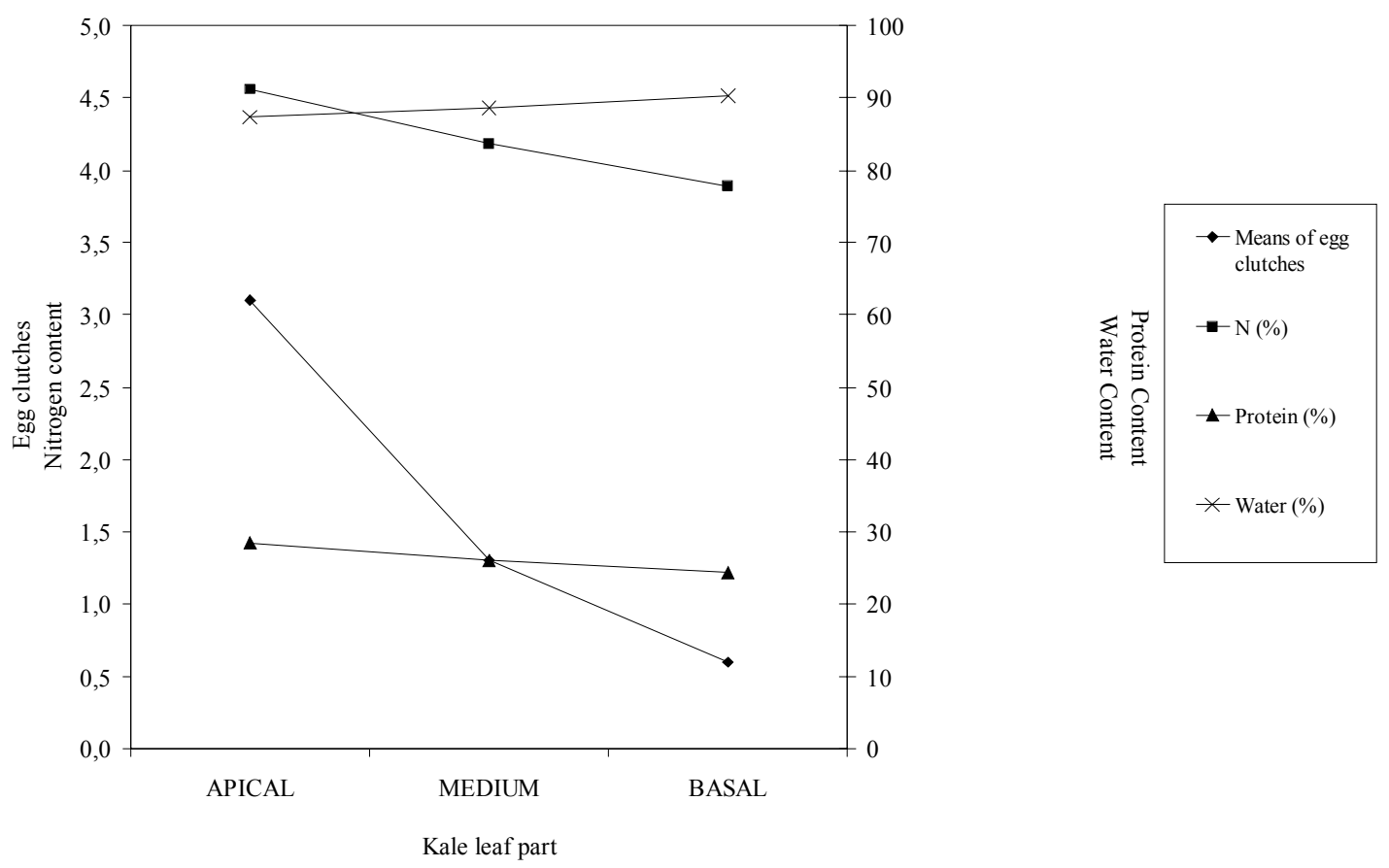

Fig. 2. Mean size of Ascia monuste (Godart, 1919) egg clutches on different kale (Brassica oleracea var. acephala) leaf parts in a greenhouse experiment $(\mathrm{n}=50)$. Comparison to the chemical composition of kale leaf parts $(\mathrm{n}=3)$.

than on the basal part. However, in greenhouse the number of egg clutches on apical part of the leaf was statistically different from both the medium and basal parts. Oviposition was more frequent on the apical part. Why do females choose these parts and why do they change their choice in greenhouse?

Many authors discuss about the preference/performance subject. The lower values of pupal mass and percentage of adult emergence, and the longer larval period on the basal leaf part indicate that this part is nutritionally poorer for this species, when compared to the apical and medium parts. Fiber content could have made the digestion more difficult and impacted digestive performance of the caterpillars on the leaf basal part. The long larval period when caterpillars are fed with the basal part of the leaves and consequently long feeding time could resulte in an equal number of egg/females for basal, medium and apical parts. But, it also would result in a higher exposure of the caterpillars to natural enemies. The best results on food consumption and utilization indices for the apical over the other leaf parts demonstrate that the apical part of the kale leaves is a better food, as it is readily digested and better utilized. This can be due to the lower fiber content of the apical part, where there are few and thin secondary nervures, which makes the digestion easier. Furthermore, pupal mass and wing size are higher on the apical part than on the medium part.

Zucoloto (1991) and Fernandes-DA-Silva \& Zucoloto (1993) suggested that nutritional differences might exist among different parts of the same host. Their results suggest that the lower part of the tested fruit may have higher nutritive value to Ceratitis capitata due to the greater concentration of sugars in that mature part. The opposite may be the case with kale leaf parts.

Total protein and nitrogen are statistically more concentrated in the older part (apical) of the leaf than in the younger ones (medium and basal). The opposite happens with water and fiber content, due to the nervure caliber. The apical part of the kale leaf grows first, contains nervures with smaller caliber, and

Table I. Performance of Ascia monuste caterpillars fed with different kale (Brassica oleracea var. acephala) leaf parts.

\begin{tabular}{lcccc}
\hline $\begin{array}{l}\text { Kale leaf } \\
\text { parts }\end{array}$ & $\begin{array}{c}\text { Larval period (days) } \\
(\mathrm{P}<0.001)\end{array}$ & $\begin{array}{c}\mathrm{AD}(\%) \\
(\mathrm{P}=0.001)\end{array}$ & $\begin{array}{c}\mathrm{ECI}(\%) \\
(\mathrm{P}=0.12)\end{array}$ & $\begin{array}{c}\mathrm{ECD}(\%) \\
(\mathrm{P}=0.02)\end{array}$ \\
\hline APICAL & $10.3 \pm 0.5 \mathrm{a}$ & $44.3 \pm 7.6 \mathrm{a}$ & $26.4 \pm 5.1 \mathrm{a}$ & $60.5 \pm 15.2 \mathrm{a}$ \\
MEDIUM & $10.2 \pm 0.4 \mathrm{a}$ & $50.4 \pm 9.9 \mathrm{~b}$ & $25.8 \pm 4.9 \mathrm{a}$ & $46.9 \pm 14.6 \mathrm{~b}$ \\
BASAL & $10.8 \pm 0.4 \mathrm{~b}$ & $41.8 \pm 6.7 \mathrm{a}$ & $23.7 \pm 4.1 \mathrm{a}$ & $56.4 \pm 14.5 \mathrm{ab}$ \\
\hline
\end{tabular}

The results represent the mean $\pm \mathrm{SD}$ of 20 experiments. Mean values followed by the same letters in the same column are not statistically different (Student-Newman-Keuls method). 
Table II. Performance of Ascia monuste pupae and adults, whose caterpillars were fed with different kale (Brassica oleracea var. acephala) leaf parts.

\begin{tabular}{lcccc}
\hline $\begin{array}{l}\text { Kale leaf } \\
\text { parts }\end{array}$ & $\begin{array}{c}\text { Pupal mass }(\mathrm{mg}) \\
(\mathrm{P}<0.001)\end{array}$ & $\begin{array}{c}\text { Emergence }(\%) \\
(\mathrm{P}=0.01)\end{array}$ & $\begin{array}{c}\text { Wing size }(\mathrm{mm}) \\
(\mathrm{P}=0.03)\end{array}$ & $\begin{array}{c}\text { No. of eggs } / \text { female } \\
(\mathrm{P}=0.77)\end{array}$ \\
\hline APICAL & $82.6 \pm 8.4 \mathrm{a}$ & $100.0 \pm 0.0 \mathrm{a}$ & $3.8 \pm 0.1 \mathrm{a}$ & $28.1 \pm 18.2 \mathrm{a}$ \\
MEDIUM & $73.9 \pm 6.6 \mathrm{~b}$ & $100.0 \pm 0.0 \mathrm{a}$ & $3.6 \pm 0.0 \mathrm{~b}$ & $32.7 \pm 25.0 \mathrm{a}$ \\
BASAL & $67.7 \pm 5.5 \mathrm{c}$ & $55.6 \pm 10.8 \mathrm{~b}$ & $3.6 \pm 0.2 \mathrm{ab}$ & $37.3 \pm 42.1 \mathrm{a}$ \\
\hline
\end{tabular}

The results represent the mean \pm SD of 15 experiments. Mean values followed by the same letters in the same column are not statistically different (Student-Newman-Keuls method).

thus ages faster than the medium and basal parts. According to SCRiber \& Fenny (1979) and Quiring (1992), plants accumulate many minerals (including nitrogen) and dissipate deterrent substances as they grow, promoting a better performance of animals feeding of them.

In studies with Tyria jacobaeae (Lepidoptera, Arctiidae), the larval development time was negatively correlated to plant nitrogen content, whereas the larval weight, growth rate and pupal weight were positively correlated to plant nitrogen content (SOLDAAT 1991 apud TinNEY et al. 1998). Low concentrations of water and nitrogen of proteins were the main factors reducing pupal mass of Epirrita autumnata (Lepidoptera, Geometridae) (KAUSE et al. 1999).

BARROS \& ZUCOLOTO (1999) also found better performance of $A$. monuste fed on kale (with more nitrogen) than on mustard. Furthermore, ovipositing attractive substances (sinigrin, alkane and glucosinolate) are found in higher concentrations in large plants (SPEnCER 1996; Spencer et al. 1997), and consequently in older leaves. These results corroborate with the conducted leaf part assay and the butterfly choice (apical part).

Ovipositing on the dorsal face of the medium part of the leaves, butterflies are covered by the leaf where they oviposit, making them invisible to birds. When a female oviposits on the apical part of the leaf, its wings are partially visible, becoming easy preys to birds.

Therefore, part of the females ovipositing on the apical leaf part could have been predated, decreasing the number of egg clutches on that leaf part. In greenhouse, predation does not occur and oviposition on the apical leaf part is more frequent than on the medium part.

Thus, the highest-value best part of the leaf (nutritionally) seems not to provide ovipositing females with enough protection against birds, making them more visibles in the field. The "enemy-free space hypothesis" (GILBERT \& SingER 1975; LAWTON 1978 apud THOMPSON 1988) suggests that performance on plant species may be influenced as much by enemies, including predators. As some examples we have Ogyris amaryllis (Lepidoptera, Lycaneidae) females that oviposit on the nutritionally inferior host Amyema maidenni (Loranthaceae) without ants rather then on the nutritionally superior $A$. preisii with ants (THOMPson 1988). Pyralid caterpillars preferred the older leaves (more suitable for rolling and producing a shelter) than younger leaves (better for growth), showing that protection was dominant over nutritional factors (DAMMAN 1987). Several authors have discussed that the predation or parasitism factories could impact (promoting lower values of larval growth and development) more than plants' lower nutritional value (Price et al. 1980; BernaYs \& Graham 1988; Yamaga \& OHGUShI 1999). ОнААКI \& SATо (1994), working with Pieridae, infer that specialist parasitoids may be one of the most important ecological factors affecting the evolution of food plant preferences. Thus, we ask if $A$. monuste is adapting its nutritional ecology (physiology and behavior) to escape from predator, as it is suggested by SCRIBER \& SLANSKY (1981).

In conclusion, we propose that good relationship between A. monuste oviposition preference and performance of offspring has been hindered by predation in field conditions.

Acknowledgments. We thank L. Mazzocato and A. P. dos Santos for technical assistance (Faculdade de Filosofia, Ciências e Letras de Ribeirão Preto, USP). Thanks to H. Vanuchi (Faculdade de Medicina de Ribeirão Preto,USP) for analyses of foliage nutrient contents. CNPq financially supported this study.

\section{REFERENCES}

Barros, H. C. H. \& F. S. Zucoloto. 1999. Performance and host preference of Ascia monuste (Lepidoptera, Pieridae). Journal of Insect Physiology 45: 7-14.

Bastos, C. S.; M. Picanço; A. P. Lôbo; E. A. Da Silva \& L. L. Neves.1997. Oviposição de Ascia monuste orseis (Godart) (Lepidoptera, Pieridae) em couve comum. Revista Brasileira de Zoologia 14(1): 187193.

Berdegué, M.; S. R. Reitz \& J. T. Trumble. 1998. Host plant selection and development in Spodoptera exigua: do mother and offspring know best? Entomologia Experimentalis et Applicata 89: 57-64.

Bernays, E. \& M. Graham. 1988. On the evolution of host specificity in phytophagous arthropods. Ecology 69(4): 886-892.

Corbitt, T. S.; S. Bryning; S. OliefF \& J. P. Edwards. 1996. Reproductive, developmental and nutritional biology of the tomato moth, Lacanobia oleracea (Lepidoptera: Noctuidae) reared on artificial diet. Bulletin of Entomological Research 86: 647-657.

CoURTNEY, S. P. 1981. Coevolution of pierid butterflies and their cruciferous foodplants. III Anthocharis cardamines (L.). Survival, development and oviposition on different host plants. Oecologia 51: 91-96.

Courtney, S. P. 1982. Coevolution of pierid butterflies and their cruciferous foodplants. IV. Crucifer apparency and Anthocharis cardamines (L.) oviposition. Oecologia 52: 252-265.

Craig, T. P.; J. K. Itami \& P. W. Price. 1989. A strong relationship between oviposition preference and larval performance in a shootgalling sawfly. Ecology 70(6): 1691-1699.

Damman, H. 1987. Leaf quality and enemy avoidance by larvae of a pyralid moth. Ecology 68(1): 87-97. 
Diniz, P. P. 1998. Aspectos da performance e dos comportamentos alimentar e de oviposição de Ascia monuste (Lepidoptera: Pieridae). Dissertação de Mestrado. Faculdade de Filosofia, Ciências e Letras de Ribeirão Preto, Universidade de São Paulo, 86 p.

Ehrlich, P. R. \& D. D. Murfhy. 1988. Plant chemistry and host range in insects herbivores. Ecology 69(4): 908-909.

Felipe, M. C. \& F. S. Zucoloto 1993. Estudos de alguns aspectos da alimentação em Ascia monuste Godart (Lepidoptera, Pieridae). Revista Brasileira de Zoologia 10(2): 333-341.

Fernandes-DA-Silva, P. G. \& F. S. Zucoloto. 1993. The influence of host nutritive value on the performance and food selection in Ceratitis capitata (Diptera, Tephritidae). Journal of Insect Physiology 39(10): 883-887.

FleCK, A. \& H. M. Munro. 1965. The determination of organic nitrogen in biological materials. Clinica Chimica Acta II: 2-12.

Gilbert, N. \& M. C. Singer. 1975. Butterfly ecology. Annual Review of Ecology and Systematics 6: 365-397.

Haussmann, S. M. \& J. R. Miller. 1989. Ovipositional preference and larval survival of the Onion maggot (Diptera: Anthomyidae) as influenced by previous maggot feeding. Journal of Economical Entomology 82(2): 425-429.

Kause, A.; V. Ossipov; E. Haukioja; K. Lempa; S. HanhimäKi \& S. Ossipova. 1999. Multiplicity of biochemical factors determining quality of growing birch leaves. Biotropica 120: 102-112.

Kouki, J. 1993. Female's preference for oviposition site and larval preformance in the water-lily beetle, Galerucella nymphacea (Coleoptera: Chrysomelidae). Oecologia 93: 42-47.

ManUgistics Inc. 1993. Multifactor analysis of variance. In: Statgraphics Plus version 7 reference manual. Manugistics, p. M61-M77.

Ohsaki, N. \& Y. Sato. 1994. Food plant choice of Pieris butterflies as a trade-off between parasitoid advoidance and quality of plants. Ecology 75(1): 59-68.

Ohsaki, N. \& Y. Sato. 1999. The role of parasitoids in evolution of habitat and larval food plant preference by three Pieris butterflies. Research of Population Ecology 41: 107-119.

Price, P. W.; C. E. Bouton; P. Gross; B. A. McPherson; J. N. Thompson \& A. E. Weiss. 1980. Interactions among three trophic levels: influence of plants on interaction between insect herbivores and natural enemies. Annual Review of Ecology and Systematics 11: 4165.

QUiRING, D. T. 1992. Rapid change in suitability of white spruce for a specialist herbivore, Zeiraphera canadensis, as a function of leaf age. Canadian Journal of Zoology 70: 2132-2138.

Rausher, M. D. 1982. Population differentiation in Euphydryas editha butterflies: larval adaptation to different hosts. Evolution 36(3): 581-590.

Rausher, M. D. 1983. Alteration of oviposition behavior by Battus philenor butterflies in response to variation in host-plant density. Ecology 64 (5): 1028-1034.

RoININEN, H. \& J. TAHVANAINEN. 1989. Host selection and larval performance of two willow-feeding sawflies. Ecology 70(1): 129-136.

Shima, S. N. \& N. GobBi. 1981. Estudos de alguns aspectos da biologia de Ascia monuste orseis (Godart, 1818) (Lepidoptera, Pieridae) em condições de laboratório e campo. Revista Brasileira de Entomologia 25(4): 313-319.

Sigmastat for Windows. 1994. Jandel Corporation.

SipuRA, M. 1999. Tritrophic interactions: willows, herbivorous insects and insectivorous birds. Oecologia 121: 537-545.

SCRIBER, J. M. \& P. Fenny. 1979. Growth of herbivorous caterpillars in relation to feeding specialization and to growth form of their food plants. Ecology 60: 829-850.

SCRIBER, J. M. \& F. SLANSKY JR. 1981. The nutritional ecology of immature insects. Annual Review of Entomology 26: 183-211.

Slansky JR, F. \& J. M. Scriber. 1985. Food consumption and utilization, p. 87-163. In: G. A. Kerkut \& L. I. Gilbert (Eds.). Comprehensive insect physiology, biochemistry and pharmacology. Vol. 4. Oxford, Pergamon Press.

Spencer, J. L. 1996. Waxes enhance Plutella xylostella oviposition in response to sinigrin and cabbage homogenates. Entomologia Experimentalis et Applicata 81: 165-173.

Spencer, J. L.; P. Satish \& E. A. Bernays. 1997. Diamondback moth behavior and oviposition in response to an alkane/sinigrin synergy. Insects and the Plant Surface-Behavior to Community. In: ESA Annual Meeting. Web page: sheridan.com/entsoc/abs/SC3/ E3305.html

Thompson, J. N. 1988. Evolutionary ecology of the relatioship between oviposition preference an offspring in phytophagous insects. Minireview. Entomologia Experimentalis et Applicata. 47: 3-14.

Thompson, J. N. \& O. Pelmyr. 1991. Evolution of oviposition behavior and host preference in Lepidoptera. Annual Review of Entomology 36: 65-89.

Tinney, G. W.; P. E. Hatcher; P. G. Ayres; N. D. Paul \& J. B. Whittaker. 1998. Inter- and intra-species differences in plants as hosts to Tyria jacobaeae. Entomologia Experimentalis et Applicata 88: 137145.

Valladares, G. \& J. H. Lawton. 1991. Host-plant selection in the holly leaf-miner: does mother know best? Animal Ecology 60: 272240.

Yamaga, Y. \& T. Ohgushi. 1999. Preference-performance linkage in a herbivorous lady beetle: consequences of variability of natural enemies. Oecologia 119: 183-190.

Zucoloto, F. S. 1991. Effects of flavor and nutritional value on a diet selection by Ceratitis capitata (Diptera: Tephritidae). Journal of Insect Physiology 37(1): 21-25. 